\title{
Biological effects of formulation containing curcuminoids and Bidens Pilosa $L$. in oral carcinoma cell line
}

\section{Diego Antonio Costa ARANTES(a) \\ Artur Christian Garcia da SILVA ${ }^{(b)}$ \\ Eliana Martins LIMA(c) \\ Ellen Cristine Pineze ALONSO(d) (id \\ Ricardo Neves MARRETO(d) (iD) \\ Elismauro Francisco MENDONÇA ${ }^{(a)}$ \\ Marize Campos VALADARES(e) (D) \\ Aline Carvalho BATISTA(a) \\ (in memorian)}

(a) Universidade Federal de Goiás - UFG, Dental School, Department of Stomatology (Oral Pathology), Goiânia, Brazil.

(b) Universidade Federal de Goiás - UFG, Pharmacy Faculty, Laboratory of Education and Research in Toxicology in Vitro, Goiânia, GO, Brazil.

(c) Universidade Federal de Goiás - UFG, Pharmacy Faculty, Laboratory of Pharmaceutical Technology, Goiânia, GO, Brazil.

(d) Universidade Federal de Goiás - UFG, Pharmacy Faculty, Laboratory of Nanosystems and Modified-Release Drugs Devices, Goiânia, GO, Brazil.

(e) Universidade Federal de Goiás - UFG, Pharmacy Faculty, Laboratory of Pharmacology and Cellular Toxicology, Goiânia, GO, Brazil.

Declaration of Interests: The authors certify that they have no commercial or associative interest that represents a conflict of interest in connection with the manuscript.

\section{Corresponding Author:}

Diego Antonio Costa Arantes

E-mail: diegoantonioarantes@gmail.com

htrps://doi.org/10.1590/1807-3107bor-2021.vol35.0063

Submitted: July 29, 2020

Accepted for publication: December 3, 2020

Last revision: January 18, 2021
Abstract: FITOPROT, which contains curcuminoids and Bidens pilosa L. extract, is an innovative mucoadhesive formulation indicated for the topical treatment of chemoradiotherapy-induced oral mucositis (OM) in patients with advanced and visible oral squamous cell carcinoma. The formulation is used as a mouthwash directly on tumor tissue of patients with advanced neoplasms, without triggering cancer cell proliferation or tumor invasiveness. Thus, the aim of this study was to evaluate the biological effects of FITOPROT on an oral squamous cell carcinoma cell line (SCC-4). The viability of SCC-4 cells was assessed after exposure to FITOPROT using MTT reduction assay. The effects of the mucoadhesive formulation on cell cycle progression and cell death parameters were evaluated using flow cytometry. In addition, the inflammatory profile of the tumor cells was evaluated using the cytometric bead array (CBA) assay. FITOPROT promoted a concentration-dependent decrease in cell viability and cell cycle arrest at the G2/M phase $(\mathrm{p}<0.05)$. Mitochondrial membrane potential was also altered after exposure to the formulation $(p<0.05)$, in parallel with a reduction in VEGF and IL-8 production ( $p=0.01$ and $p=0.05$, respectively). In summary, the results indicate that FITOPROT reduces SCC-4 cell viability, promotes cell cycle arrest, modulates mitochondrial membrane potential, and exhibits antiangiogenic and anti-inflammatory properties, thus indicating its potential for topical use in patients with OM and visible tumors in the mouth.

Keywords: Carcinoma, Squamous Cell; Bidens; Curcumin; Cell Survival; Cell Cycle Checkpoints.

\section{Introduction}

Oral squamous cell carcinoma (OSCC) is a malignant neoplasm of epithelial nature that corresponds to $90 \%$ of all cancers found in the oral cavity. ${ }^{1}$ The majority of patients present with advanced clinical stage (III and IV) and are treated by neoadjuvant radiotherapy (RT) alone or in combination with chemotherapy $(\mathrm{QT})^{2}$, which is a therapeutic strategy associated with excellent overall survival rates. ${ }^{3,4}$ However, these therapeutic protocols are generally associated with the occurrence of serious side effects in the oral mucosa that are difficult to treat, such as chemoradiotherapy-induced oral mucositis (OM). ${ }^{5}$ 
Chemotherapy- or radiotherapy-induced OM is a debilitating inflammatory condition whose ulcerated or severe forms may result in the interruption of cancer treatment and cause negative effects on the survival and quality of life of patients with OSCC. ${ }^{5,6}$ In this context, our research group developed an innovative mucoadhesive formulation (mouthwash) based on curcuminoids and a glycerinated extract of Bidens pilosa L. for the topical treatment of $\mathrm{OM}$, which has shown promising results in vivo (experimental animal models), ${ }^{7}$ in vitro, ${ }^{8}$ and in clinical studies (Phase I). ${ }^{9}$ A pre-clinical study (in vivo) was undertaken using an experimental animal model of intestinal mucositis to evaluate the safety and efficacy of this phytomedication. In that study, it was shown that FITOPROT exerted anti-ulcerative, anti-inflammatory, and antioxidant activities. $^{7}$ The same research group later showed that the mucoadhesive formulation presented cytoprotective capacity in normal keratinocytes cells (in vitro) ${ }^{8}$ induced with 5 -fluorouracil (5-FU) damage and it was clinically safe in healthy volunteers (Phase I randomized clinical trial) thus showing an important potential for the treatment of $\mathrm{OM}$ in patients with OSCC in advanced stage and with visible lesions in the mouth. ${ }^{9}$ Recently, a phase II clinical trial is being developed (finalizing the patient recruitment stage) to assess the safety and efficacy of FITOPROT used by cancer patients (Figure 1).

In addition to these biological properties that are important for the treatment of OM, other studies have demonstrated the antineoplastic potential of curcuminoids and Bidens pilosa $\mathrm{L}$., and its action on the signaling pathways of cell proliferation of epithelial and hematopoietic tumors. ${ }^{10,11,12,13}$ Furthermore, in vitro studies have indicated that these extracts have an antiproliferative capacity through the blockade of cell cycle phases and the induction of apoptosis. ${ }^{10,11,12,13}$ In addition, curcumin also demonstrated the ability to reduce tumor size, especially those associated with other forms of cancer treatment, in experimental animal models. ${ }^{13}$

Considering previous evaluations of the safety and efficacy of FITOPROT, patients with OSCC diagnosed in advanced stages, without the

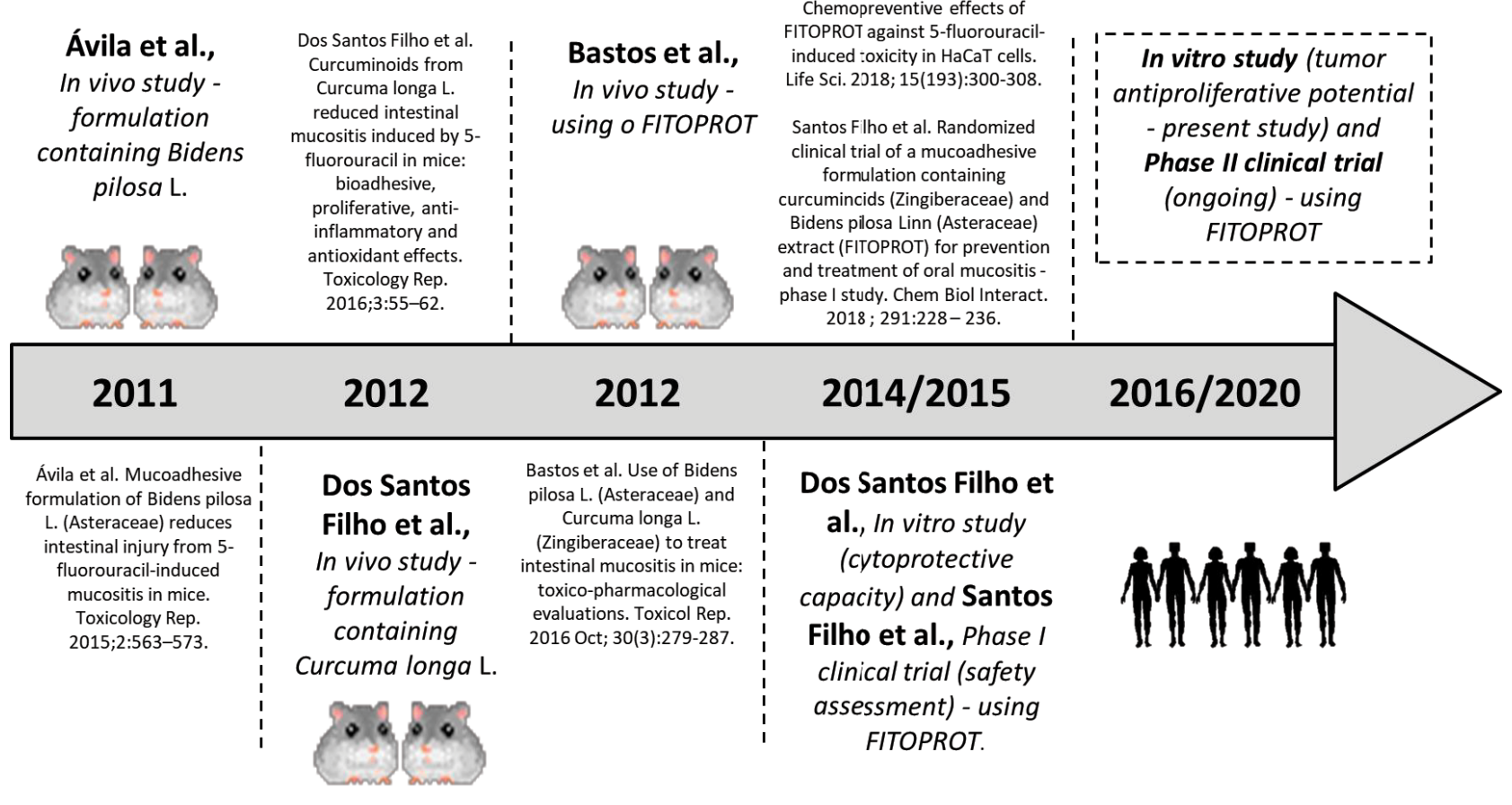

Figure 1. Schematic representation of studies performed and in progress using FITOPROT. 
possibility of immediate surgical resection and who are submitted to neoadjuvant RT/QRT, can use the mouthwash safely over the tumor. Thus, the in vitro evaluation of the biological effects of this phytomedication on neoplastic cells, complementing the preclinical evaluations, was necessary. ${ }^{7,9}$ The objective of this in vitro study was to evaluate the biological effects of FITOPROT, which contains curcuminoids in association with Bidens Pilosa L. extract, using a cell line of oral squamous cell carcinoma (SCC-4). It is believed that FITOPROT does not promote OSCC neoplastic cell proliferation and it can be used to treat $\mathrm{OM}$ in cancer patients.

\section{Methodology}

\section{Cell culture}

Oral squamous carcinoma cells (SCC-4), acquired from the American Type Culture Collection (Rockville, MD, USA), were cultivated in a mixture of Dulbecco's modified Eagle's medium (DMEM):Ham's F12 medium (1:1) (Sigma-Aldrich, St. Louis, USA), supplemented with $10 \%$ fetal bovine serum (Invitrogen/Life Technologies, Carlsbad, USA), l-glutamine (2 $\mathrm{mM})$, sodium pyruvate $(0.5 \mathrm{mM})$, hydrocortisone $(500 \mathrm{ng} / \mathrm{mL})$ (Sigma-Aldrich, St. Louis, USA), penicillin (100 IU/mL), and streptomycin $(100 \mu \mathrm{g} / \mathrm{mL})$ (Invitrogen/Life Technologies, Carlsbad, USA). During cultivation, the cells were incubated in a humidified atmosphere with $5 \% \mathrm{CO}_{2}$ at $37^{\circ} \mathrm{C}$. Cell viability $>90 \%$ was considered as adequate to carry out the proposed assays.

\section{Cytotoxicity assay and exposure of SCC-4 cells to FITOPROT}

Cytotoxicity assay was performed using the tetrazolium salt reduction assay [3-(4,5-dimethylthiazol-2-yl)-2,5-diphenyltetrazolium bromide (MTT)] ${ }^{14}$ The SCC- 4 cells were cultivated in 96-well plates overnight $\left(1.5 \times 10^{4}\right.$ cells/well). Then, they were treated with decreasing concentrations of FITOPROT ( $2 \%-0.01 \%)$, which were experimentally determined by Santos Filho et al., ${ }^{8}$ for $24 \mathrm{~h}$ and incubated with culture medium containing MTT $(0.5 \mathrm{mg} / \mathrm{mL})$. After $3 \mathrm{~h}$ of incubation, the formazan crystals were dissolved in dimethyl sulfoxide
(DMSO) $(100 \mu \mathrm{L} /$ well), and the optical density was measured using a microplate reader (Thermo Fisher Scientific, Waltham, USA) at 560nm. This assay was performed in sextuplicate. The relative cell viability was determined in comparison to the negative control (unexposed cells) for establishment of non-cytotoxic concentrations that were employed in further mechanistic analyses.

\section{Cell cycle progression analysis}

To evaluate the influence of the mucoadhesive formulation on cell cycle phases, the SCC- 4 cells were seeded in 6-well plates $\left(3.0 \times 10^{5}\right.$ cells/well $)$ and treated with FITOPROT for $24 \mathrm{~h}$ using the inhibitory concentration of $20 \%$ of cell growth $\left(\mathrm{IC}_{20}\right)$, which was previously determined in the cytotoxicity assay. After this period, the cells were harvested by trypsinization and fixed with $1.0 \mathrm{~mL}$ of $70 \%$ ice-cold ethanol. After fixation, the cells were incubated for $1 \mathrm{~h}$ with a solution of RNAse $(200 \mu \mathrm{g} / \mathrm{mL})$ and propidium iodide ( $50 \mu \mathrm{g} / \mathrm{mL}$ ) (both from Sigma-Aldrich, St. Louis, USA) and then washed with phosphate-buffered saline (PBS) for further assessment in a flow cytometer (BD FACSCANTO II, BD Bioscience, USA). This assay was performed in sextuplicate.

\section{Mitochondrial membrane potential $(\Delta \Psi \mathrm{m})$ assessment}

Rhodamine 123 staining was used for the evaluation of the mitochondrial membrane potential $(\triangle \Psi \mathrm{m})$. The SCC- 4 cells $\left(3.0 \times 10^{5}\right.$ cells/well $)$ were seeded in 6-well culture plates and pretreated with $\mathrm{IC}_{20}$ of FITOPROT for $24 \mathrm{~h}$. After exposure, the cells were washed using PBS and then incubated with $200 \mu \mathrm{L}$ of rhodamine $123(1 \mu \mathrm{g} / \mathrm{mL})$ (Sigma-Aldrich, St. Louis, USA) at $37^{\circ} \mathrm{C}$ for $1 \mathrm{~h}$, followed by another wash using PBS. The cells were then suspended in $200 \mu \mathrm{L}$ of PBS and again incubated at $37^{\circ} \mathrm{C}$ for 20 min before being analyzed in a flow cytometer (BD FACSCANTO II, BD Bioscience, USA). This assay was performed in sextuplicate.

\section{Evaluation of caspase activity in SCC-4 cells after exposure to FITOPROT}

The expression of caspases $3 / 7,8$, and 9 was analyzed in sextuplicate using the CaspaTag ${ }^{\mathrm{TM}}$ in situ 
assay kit (Millipore ${ }^{\mathrm{TM}}$, Temecula, USA). The SCC-4 cells were pretreated with FITOPROT $\left(\mathrm{IC}_{20}\right)$ for $24 \mathrm{~h}$ and then washed with $2.0 \mathrm{~mL}$ of PBS, centrifuged at $1500 \mathrm{rpm}$ for $5 \mathrm{~min}$, and incubated at $37^{\circ} \mathrm{C}$ with $10 \mu \mathrm{L}$ of the corresponding reagent for each caspase for $1 \mathrm{~h}$. After incubation, the cells were washed twice with $2.0 \mathrm{~mL}$ of PBS, resuspended in $200 \mu \mathrm{L}$ of PBS, and then analyzed by flow cytometry.

\section{Expression analysis of proteins involved in proliferative (Ki-67 and cyclin D1), cell death pathways (cytochrome $c$ ), and angiogenesis (VEGF)}

The SCC- 4 cells $\left(2.5 \times 10^{5}\right.$ cells $\left./ \mathrm{mL}\right)$ were seeded in $75-\mathrm{cm}^{2}$ flasks and incubated overnight for adhesion. Cells were then treated with $\mathrm{IC}_{20}$ of FITOPROT for 24 $h$. Then, the untreated and treated cells were washed twice with PBS-BSA $(0.1 \%, \mathrm{w} / \mathrm{v})$ and centrifuged at $1,500 \mathrm{rpm}$ for $5 \mathrm{~min}$ at $25^{\circ} \mathrm{C}$. Next, the cells were suspended with BD Cytofix/Cytoperm ${ }^{\mathrm{TM}}$ solution and incubated at $4^{\circ} \mathrm{C}$ for $20 \mathrm{~min}$. This was followed by washing twice with PBS-Tween $20(0.05 \%)$, after which the cells were centrifuged $\left(1,500 \mathrm{rpm}, 25^{\circ} \mathrm{C}\right.$, for $5 \mathrm{~min}$ ) and incubated with specific monoclonal antibodies [FITC-conjugated anti-Ki-67 (MIB-1, DAKO), FITC-conjugated anti-cyclin D1 (G124-326, BD Biosciences), FITC-conjugated anti-cytochrome c (sc-13561), or FITC-conjugated anti-VEGF (Alexa Fluor 488 Conjugated - IC2931G, RD Systems)] in the dark for $30 \mathrm{~min}$ at room temperature. After incubation, the cells were again washed twice with PBS-Tween 20, centrifuged at 1,500 rpm for $5 \mathrm{~min}$ at $25^{\circ} \mathrm{C}$, and suspended in $200 \mu \mathrm{L}$ of PBS for flow cytometry analysis. This assay was performed in triplicate.

\section{Measurement of inflammatory cytokines}

The SCC- 4 cells $\left(7.5 \times 10^{4}\right.$ cells/well) were seeded in 24-well culture plates and then treated with $\mathrm{IC}_{20}$ of FITOPROT for $24 \mathrm{~h}$. After treatment, the cells were washed twice with PBS $(1 \mathrm{~mL} /$ well $)$ and cell lysates were obtained treating with $250 \mu \mathrm{L} /$ well of PBS solution containing $0.5 \%(\mathrm{v} / \mathrm{v})$ Triton X-100 and a protease inhibitor cocktail (Sigma-Aldrich, St. Louis, USA). The cell lysates were stored at $-80^{\circ} \mathrm{C}$ until analysis. The concentrations of the cytokines interleukin (IL)-6, IL-1 $\beta$, IL-8, IL-12p70, IL-10, and TNF- $\alpha$ were evaluated by cytometric bead array (CBA) assay, using the human inflammatory cytokine kit (BD Bioscience, cat. no. 551811, San Diego, USA). Fluorescence was measured using flow cytometry [FACSCantoll flow cytometer with a 407$\mathrm{nm}$ laser capable of detecting and distinguishing fluorescence emission between 576 and $670 \mathrm{~nm}$ (BD Bioscience)], where 2000 events were obtained using BDFACSDiva $^{\mathrm{TM}}$ software and analyzed using the FCAP Array ${ }^{\mathrm{TM}}$ software. The Bradford assay using bovine serum albumin (Fermentas Life Sciences, Vilnius, Lithuania) was carried out to measure the total protein concentration (PerlongDNM-9602 Microplate Reader, Buena Park, USA) using a standard curve. The cytokine concentration values, corrected by the total protein value in the cell lysates, were expressed in picogram per milligram of protein.

\section{Statistical analysis}

Data obtained from the cytotoxicity tests, the cell cycle progression assays, and the expression analysis of Ki-67, cyclin D1, cytochrome c, caspases, and VEGF and inflammatory cytokines (IL-6, IL-1 $\beta$, IL-8, IL-12p70, IL-10, and TNF- $\alpha$ ) were expressed as median and minimum and maximum values. The Shapiro-Wilk test was used to evaluate data normality. Percentage viability relative to that of control (cells not exposed to compounds) and the $\mathrm{IC}_{50}$ and $\mathrm{IC}_{20}$ values were determined using nonlinear regression analysis. ANOVA and Student's $t$-tests were used to evaluate cell viability, cell cycle phases, and expression of Ki-67, cyclin D1, cytochrome c caspase activity and VEGF by flow cytometry in the groups. The Mann-Whitney test was used to compare the treated and control groups in terms of the concentration of inflammatory cytokines.

A statistical significance level of $5 \%(p \leq 0.05)$ was used for all statistical tests, and data were analyzed using the Statistical Package for Social Sciences program (SPSS for Windows, version 23.0, SPSS Inc., Chicago, USA) and the GraphPad Prism 5.01 software (GraphPad Inc., San Diego, USA). 


\section{Results}

\section{Viability of SCC- 4 cells exposed to FITOPROT}

The MTT assay results indicated that treatment with FITOPROT significantly reduced the viability of treated SCC- 4 cells $\left(\mathrm{IC}_{50}=0.1 \%\right)$ compared to that of control cells $(p=0.01)$ (Figure 2$)$.

\section{Effects of FITOPROT on cell cycle progression and proliferation}

Cell cycle progression assay was carried out using flow cytometry to identify the cell cycle phases (sub-G1, G0/G1, S, and G2/M) in each individual cell. The results revealed a smaller number of FITOPROT-treated SCC-4 cells in the G0/ G1 phase (preparation for cell division) compared to that of control $(p=0.006)$. The number of cells in the synthesis phase ( $\mathrm{S}$ phase) was similar in both groups $(p>0.05)$. In addition to a reduced number of cells in the G0/G1 phase and nonreturn to the interphase, there was a significant increase in the treated SCC- 4 cells that remained in the $\mathrm{G} 2 / \mathrm{M}$ phase compared to that in the control group $(p=0.01)$ (Figure 3$)$. Furthermore, the expression of Ki-67 and cyclin D1 cell proliferation proteins by FITOPROT-treated SCC-4 cells was similar to that in the control group ( $p>0.05)$, indicating an absence of proliferation stimuli by the mucoadhesive formulation.

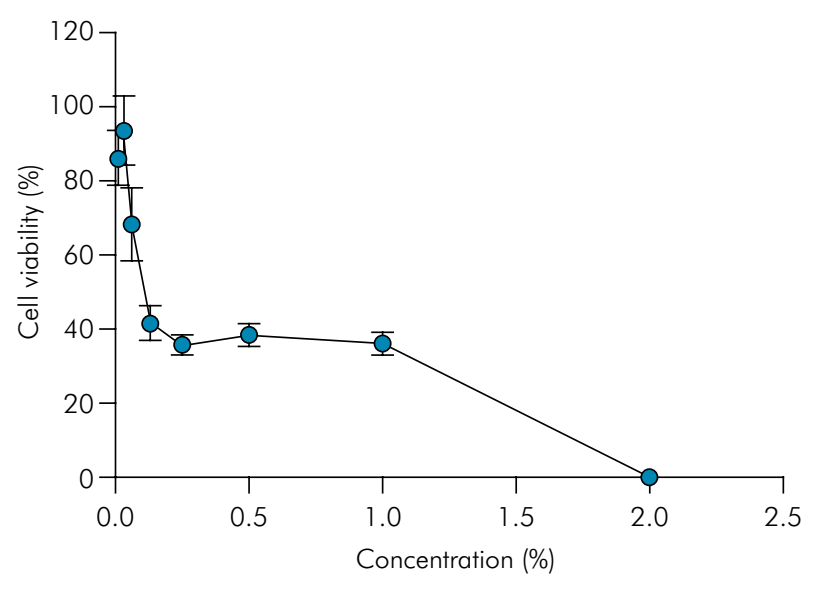

Figure 2. Reduction in viability (\%) of FITOPROT-treated SCC4 cells $\left(I C_{20}=0.0625 \%\right.$ and $\left.I C_{50}=0.1 \%\right)$.

\section{Effects of FITOPROT on mitochondrial membrane potential $(\Delta \Psi \mathrm{m})$, caspase activity, and cytochrome c release}

Accumulation of rhodamine 123 in the mitochondrial matrix was significantly higher in the SCC-4 group treated with FITOPROT $\left(\mathrm{IC}_{20}\right)$ than in the control group $(p=0.006)$ (Figure 4), demonstrating a possible mitochondrial membrane hyperpolarization. On the other hand, the expression of cytochrome c and caspases $3 / 7,8$, and 9 by SCC- 4 cells treated with

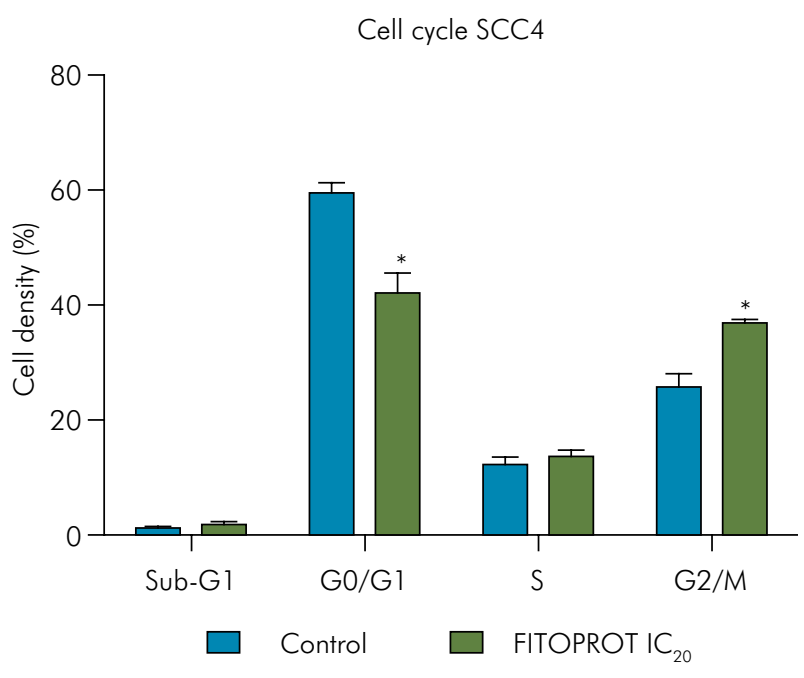

Figure 3. Distribution of SCC-4 cell density (\%) in each phase of the interphase (sub-G1, G0/G1 , S, and G2/M). *Statistically significant difference between groups (ANOVA test).

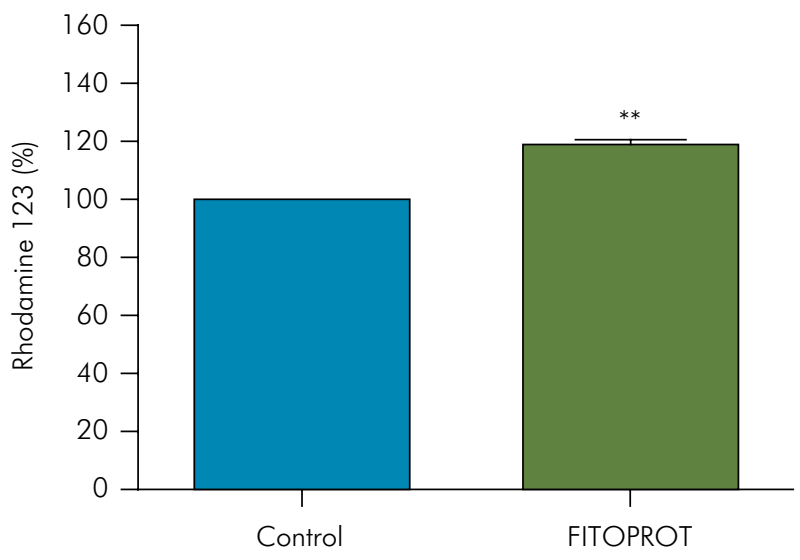

Figure 4. Mean Rhodamine 123 fluorescence in FITOPROTtreated SCC-4 cells $\left(\mathrm{IC}_{20}\right)$ and control. *Statistically significant difference between groups (Student's t-test). 
FITOPROT $\left(\mathrm{IC}_{20}\right)$ was similar to that in the control group $(\mathrm{p}>0.05)$.

\section{VEGF, TNF- $\alpha$, IL-6, IL-1 $\beta$, IL-8, IL-12p70, and IL-10 production}

Regarding the antiangiogenic property of FITOPROT, there was a significant decrease in VEGF production in the group of SCC-4 cells treated with the formulation $\left(\mathrm{IC}_{20}\right)$ when compared to that in the untreated SCC-4 cells ( $p=0.01$ ) (Figure 5).

Evaluation of the cell lysates revealed a lower IL-8 cytokine production by the FITOPROT-treated SCC -4 cells than that in the control group $(\mathrm{p}=0.05)$. In addition, FITOPROT did not induce increased production of the cytokines TNF- $\alpha$, IL-6, IL-1 $\beta$, IL-12p70, and IL-10 by the SCC- 4 cells, with the concentrations being similar to those in the control group $(\mathrm{p}>0.05)$ (Table).

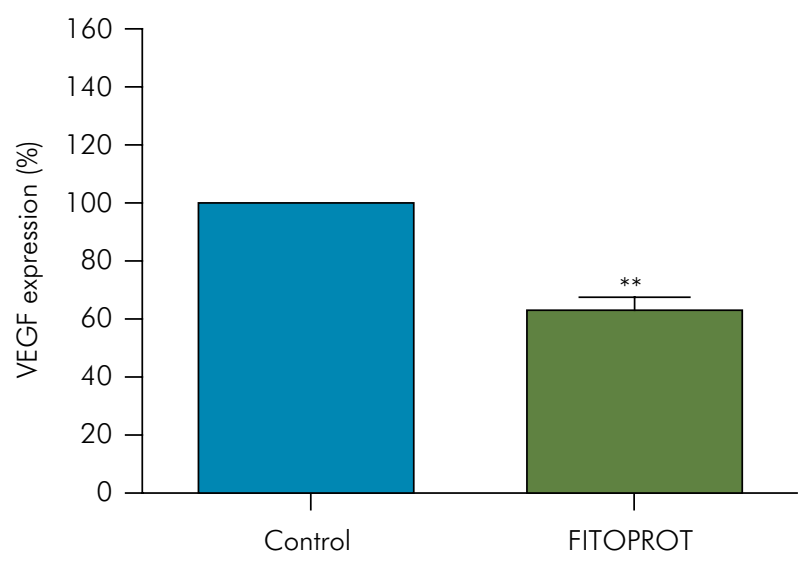

Figure 5. Mean VEGF production by FITOPROT-treated SCC-4 cells $\left(\mathrm{IC}_{20}\right)$ and control group. *Statistically significant difference between groups (Student's t-test).

\section{Discussion}

Our in vitro study findings showed that FITOPROT does not induce tumor proliferation, as observed by the compromising cell viability, and it reduced the number of cells preparing to divide (G0/G1 phase) and prevented their return to the interphase by maintaining them in the $\mathrm{G} 2 / \mathrm{M}$ phase checkpoint. Consistent with our findings, Ip et al. ${ }^{15}$ observed that curcumin inhibits the growth of the SCC- 4 cell line and induces cell death in a dose-dependent manner, promoting the arrest of G2/M phase. In addition, Mazzarino et al. ${ }^{16}$ demonstrated that in vitro exposure to curcumin loaded with mucoadhesive nanoparticles for $24 \mathrm{~h}$ caused a significant reduction in the viability of SCC-9 human oral cancer cells. It has also been reported that curcumin acts synergistically with epigallocatechin-3-gallate, a blocker of the G2 phase, and thereby inhibits the growth of tumor cells. ${ }^{17}$

A recently published systematic review highlighted that curcumin exhibited antiproliferative capacity in head and neck tumor cells in all the in vitro studies evaluated. Furthermore, an increase in pro-apoptotic and a reduction in anti-apoptotic proteins were observed in some studies. ${ }^{13}$ Curcumin also exhibited the ability to reduce tumor size in experimental animal models, especially when associated with other forms of cancer treatment. This reduction in tumor size was accompanied by an increase in pro-apoptotic proteins (caspases 3, 8, and 9, cytochrome c, and Bax) and a reduction in anti-apoptotic proteins (BCL-2, PCNA, XIAP, and C-FLIP) and cell cycle protein (cyclin D1). ${ }^{13}$ Regarding Bidens pilos $\mathrm{L}$. (the other active principle of

Table. Effects of FITOPROT (0.0625\%) on the levels $(\mathrm{pg} / \mathrm{mg})$ of inflammatory cytokines produced by SCC4 cells.

\begin{tabular}{lccc}
\hline \multirow{2}{*}{ Cytokine level (pg/mg) } & Control & FITOPROT-treated SCC4 cells & \\
\cline { 2 - 3 } & Median (Min-Max) & Median (Min-Max) & 0.27 \\
TNF- $\alpha$ & $11.94(9.44-13.31)$ & $19.94(11.88-24.26)$ & 0.12 \\
IL-6 & $218.56(28.43-243.87)$ & $32.26(10.61-695.02)$ & 0.12 \\
IL-1 $\beta$ & $49.82(17.43-75.49)$ & $15.34(9.64-19.83)$ & $0.05^{*}$ \\
IL-8 & $874.53(725.04-1835.67)$ & $11.95(6.49-708.77)$ & 0.82 \\
IL12p70 & $8.36(8.06-12.63)$ & $18.17(11.88-20.53)$ & 0.13 \\
IL-10 & $2.24(0-3.31)$ & $10.59(0-11.88)$ & \\
\hline
\end{tabular}

*Statistically significant difference between groups (Mann-Whitney test). 
FITOPROT), Wu et al..$^{11}$ demonstrated that this extract reduces cell viability and exhibits antiproliferative and proapoptotic activities in colorectal cancer cells.

Regarding cell death induction mechanisms, FITOPROT promoted a hyperpolarization of the internal mitochondrial membrane, which was demonstrated by rhodamine 123 staining by the treated tumor cells. We hypothesized that this biological event induced by curcuminoids and Bidens pilos $a$ L. may precede the release of apoptosis signaling proteins and DNA fragmentation. The interaction of chemical substances with the mitochondria can impede the exchange of ATP between the internal microenvironment of this organelle and the cellular cytosol, thus resulting in hyperpolarization. This process precedes mitochondrial rupture and the release of apoptosis-promoting factors responsible for DNA fragmentation and phosphatidylserine externalization. ${ }^{18}$ Although alteration in some apoptotic signals in FITOPROT-treated SCC-4 cells was not observed (caspase activation and cytochrome c release), probably due to treatment time, mitochondrial alterations showed impairment in cellular homeostasis, which can trigger different cell death pathways. Similar to our findings, Alcazar et al. ${ }^{19}$ demonstrated that treating $\mathrm{T}$ lymphocytes with the chemical camptothecin for $3 \mathrm{~h}$ promoted the hyperpolarization of the mitochondrial membrane followed by the release of cytochrome $\mathrm{c}$ in the cellular cytosol. Recently, Ma et al..$^{20}$ showed that treating T-cell lymphomas with celecoxib promoted an increased expression of Bax and rhodamine 123 accumulation by the tumor cells, as well as an induction of tumor apoptosis.

In addition to these biological effects, FITOPROT also demonstrated the ability to reduce VEGF expression by SCC- 4 cells, showing an antiangiogenic potential that could compromise OSCC proliferation and invasion. Tissue expression of VEGF has been recently indicated as a marker of metastasis and tumor recurrence in patients with OSCC, ${ }^{21}$ and, therefore, regulating the expression of this inflammatory mediator may be an important option for the control of tumor progression. Furthermore, Pan et al. ${ }^{22}$ demonstrated the ability of curcumin to reduce VEGF expression in vitro in a hepatocellular carcinoma cell line associated with tumor size reduction in vivo of the same tumor. In addition, Lou et al. ${ }^{23}$ observed that curcumin was able to suppress VEGF in primary endothelial cells of a human infant hemangioma cell line. Consistent with these published data, Huang et al. ${ }^{24}$ indicated that curcumin can be used as a novel therapeutic target for angiogenesis by inhibiting NF-KB/VEGF signaling in mesenchymal stem cells derived from human gastric carcinoma. Regarding the other inflammatory mediators, we observed maintenance of TNF- $\alpha$, IL-1 $\beta$, IL-6, IL-12p70, and IL-10 levels and a reduction in IL-8 concentration in the FITOPROT-treated SCC-4 cells. Taken together, these results indicate that the mucoadhesive formulation contributes to the control of the inflammatory response in the OSCC tumor microenvironment. Jin et al..$^{25}$ demonstrated that the mRNA levels of IL-8, JAK, and STAT3 (jointly responsible for angiogenesis) in the colorectal carcinoma cell lineage were reduced after treatment with curcumin combined with epigallocatechin-3gallate. Contributing to the above-described antiinflammatory properties of curcumin, Fei et al. ${ }^{26}$ demonstrated that treatment with Bidens pilosa L. promotes a reduction in the levels of IL- 8 and TNF- $\alpha$ in vascular endothelial cell supernatants obtained from patients with Henoch-Schonlein purpura.

In conjunction, these results demonstrated that FITOPROT does not promote cancer cell proliferation but may impair some tumor-derived cell functions instead. However, evaluation of a larger number of oral carcinoma cell lines may increase the robustness of such outcomes and allow the assessment of such effects in other cancer phenotypes. As observed by our group in a previous study, ${ }^{8}$ the formulation does not promote such alterations in normal keratinocytes and, additionally, acts protecting these cells from chemically-induced damage, restoring cell redox basal status, mitochondrial function, and proliferative activity. ${ }^{8}$

\section{Conclusions}

This in vitro study demonstrated that FITOPROT has antiproliferative, antiangiogenic, and antiinflammatory properties upon SCC-4 cells. However, 
further investigation of the specific mechanisms of action that favor these antitumor properties is necessary. Furthermore, the findings demonstrated that FITOPROT did not exert negative effects in evaluated cancer cells, such as increase in cell proliferation and tumor invasiveness. Therefore, we suggest that this formulation can be potentially used in the form of a mouthwash by patients with chemoradiotherapy-induced $\mathrm{OM}$ and visible tumors in the mouth.

\section{Acknowledgements}

The authors thank Brazilian research funding agencies, Financiadora de Estudos e Projetos (FINEP, No.BR 1020130033162 - coordinated by Dr. Marize Campos Valadares), the National Council for Scientific and Technological Development (CNPq) (No. 401029/2013-1), the Coordination for Improvement of Higher Education Personnel (CAPES), and the FBMFarma company (CNPJ: 02.060.549/0001- 05), for partially funding this study.

\section{References}

1. Johnson NW, Jayasekara P, Amarasinghe AA. Squamous cell carcinoma and precursor lesions of the oral cavity: epidemiology and aetiology. Periodontol 2000. 2011 Oct;57(1):19-37. https://doi.org/10.1111/j.1600-0757.2011.00401.x

2. Eder-Czembirek C, Czembirek C, Selzer E. Neoadjuvant radiotherapy plus radical surgery for locally advanced stage III/IV oral cancer: analysis of prognostic factors affecting overall survival. Oral Oncol. 2016 Sep;60:1-7. https://doi.org/10.1016/j.oraloncology.2016.06.014

3. Freier K, Engel M, Lindel K, Flechtenmacher C, Mühling J, Hassfeld S, et al. Neoadjuvant concurrent radiochemotherapy followed by surgery in advanced oral squamous cell carcinoma (OSCC): a retrospective analysis of 207 patients. Oral Oncol. 2008 Feb;44(2):116-23. https://doi.org/10.1016/j.oraloncology.2007.01.006

4. Klug C, Berzaczy D, Voracek M, Nell C, Ploder O, Millesi W, et al. Preoperative radiochemotherapy in the treatment of advanced oral cancer: outcome of 276 patients. J Craniomaxillofac Surg. 2009 Sep;37(6):344-7. https://doi.org/10.1016/j.jcms.2008.11.012

5. Sonis ST. Oral mucositis. Anticancer Drugs. 2011 Aug;22(7):607-12. https://doi.org/10.1097/CAD.0b013e3283462086

6. Hammerlid E, Bjordal K, Ahlner-Elmqvist M, Boysen M, Evensen JF, Biörklund A, et al. A prospective study of quality of life in head and neck cancer patients. Part I: at diagnosis. Laryngoscope. 2001 Apr;111(4 Pt 1):669-80. https://doi.org/10.1097/00005537-200104000-00021

7. Bastos CC, Ávila PH, Santos Filho EX, Ávila RI, Batista AC, Fonseca SG, et al. Use of Bidens pilosa L. (Asteraceae) and Curcuma longa L. (Zingiberaceae) to treat intestinal mucositis in mice: toxico-pharmacological evaluations. Toxicol Rep. 2015 Oct;3:279-87. https://doi.org/10.1016/j.toxrep.2015.10.013

8. Santos Filho EX, Silva AC, Ávila RI, Batista AC, Marreto RN, Lima EM, et al. Chemopreventive effects of FITOPROT against 5-fluorouracil-induced toxicity in HaCaT cells. Life Sci. 2018 Jan;193(193):300-8. https://doi.org/10.1016/i.lfs.2017.09.035

9. Santos Filho EX, Arantes DA, Oton Leite AF, Batista AC, Mendonça EF, Marreto RN, et al. Randomized clinical trial of a mucoadhesive formulation containing curcuminoids (Zingiberaceae) and Bidens pilosa Linn (Asteraceae) extract (FITOPROT) for prevention and treatment of oral mucositis - phase I study. Chem Biol Interact. 2018 Aug;291:228-36. https://doi.org/10.1016/i.cbi.2018.06.010

10. Ong PL, Weng BC, Lu FJ, Lin ML, Chang TT, Hung RP, et al. The anticancer effect of protein-extract from Bidens alba in human colorectal carcinoma SW480 cells via the reactive oxidative species- and glutathione depletion-dependent apoptosis. Food Chem Toxicol. 2008 May;46(5):1535-47. https://doi.org/10.1016/i.fct.2007.12.015

11. Wu J, Wan Z, Yi J, Wu Y, Peng W, Wu J. Investigation of the extracts from Bidens pilosa Linn. var. radiata Sch. Bip. for antioxidant activities and cytotoxicity against human tumor cells. J Nat Med. 2013 Jan;67(1):17-26. https://doi.org/10.1007/s11418-012-0639-x

12. Panda AK, Chakraborty D, Sarkar I, Khan T, Sa G. New insights into therapeutic activity and anticancer properties of curcumin. J Exp Pharmacol. 2017 Mar;9:31-45. https://doi.org/10.2147/JEP.S70568

13. Borges GA, Rêgo DF, Assad DX, Coletta RD, Canto GL, Guerra EN. In vivo and in vitro effects of curcumin on head and neck carcinoma: a systematic review. J Oral Pathol Med. 2017 Jan;46(1):3-20. https://doi.org/10.1111/jop.12455

14. Nogueira IA, Leão AB, Vieira MS, Benfica PL, Cunha LC, Valadares MC. Antitumoral and antiangiogenic activity of Synadenium umbellatum Pax. J Ethnopharmacol. 2008 Dec;120(3):474-8. https://doi.org/10.1016/i.jep.2008.08.026

15. Ip SW, Wu SY, Yu CC, Kuo CL, Yu CS, Yang JS, et al. Induction of apoptotic death by curcumin in human tongue squamous cell carcinoma SCC-4 cells is mediated through endoplasmic reticulum stress and mitochondria-dependent pathways. Cell Biochem Funct. 2011 Dec;29(8):641-50. https://doi.org/10.1002/cbf.1800 
16. Mazzarino L, Loch-Neckel G, Bubniak LS, Mazzucco S, Santos-Silva MC, Borsali R, et al. Curcumin-loaded chitosan-coated nanoparticles as a new approach for the local treatment of oral cavity cancer. J Nanosci Nanotechnol. 2015 Jan;15(1):781-91. https://doi.org/10.1166/jnn.2015.9189

17. Chakraborty S, Sarkar T, Roy D, Bhattacharya A, Chakraborty D, Sa G, et al. Multi-edged sword against cancer: ancient exotic spice. Indian J Physiol Allied Sci. 2014;68:129-50.

18. Ly JD, Grubb DR, Lawen A. The mitochondrial membrane potential (deltapsi(m)) in apoptosis; an update. Apoptosis. 2003 Mar;8(2):115-28. https://doi.org/10.1023/A:1022945107762

19. Sánchez-Alcázar JA, Ault JG, Khodjakov A, Schneider E. Increased mitochondrial cytochrome c levels and mitochondrial hyperpolarization precede camptothecin-induced apoptosis in Jurkat cells. Cell Death Differ. 2000 Nov;7(11):1090-100. https://doi.org/10.1038/sj.cdd.4400740

20. Ma M, Yang X, Zhao L, Wang X, Liu L, Jiao W, et al. Celecoxib enhances sensitivity to chemotherapy drugs of T-cell lymphoma. Oncol Lett. 2018 Apr;15(4):4649-56. https://doi.org/10.3892/ol.2018.7897

21. Lee LT, Wong YK, Chan MY, Chang KW, Chen SC, Chang CT, et al. The correlation between HIF-1 alpha and VEGF in oral squamous cell carcinomas: expression patterns and quantitative immunohistochemical analysis. J Chin Med Assoc. 2018 Apr;81(4):370-5. https://doi.org/10.1016/i.jcma.2017.06.025

22. Pan Z, Zhuang J, Ji C, Cai Z, Liao W, Huang Z. Curcumin inhibits hepatocellular carcinoma growth by targeting VEGF expression. Oncol Lett. 2018 Apr;15(4):4821-6. https://doi.org/10.3892/ol.2018.7988

23. Lou S, Wang Y, Yu Z, Guan K, Kan Q. Curcumin induces apoptosis and inhibits proliferation in infantile hemangioma endothelial cells via downregulation of MCL-1 and HIF-1 $\alpha$. Medicine (Baltimore). 2018 Feb;97(7):e9562. https://doi.org/10.1097/MD.0000000000009562

24. Huang F, Yao Y, Wu J, Liu Q, Zhang J, Pu X, et al. Curcumin inhibits gastric cancer-derived mesenchymal stem cells mediated angiogenesis by regulating NF-kB/VEGF signaling. Am J Transl Res. 2017 Dec;9(12):5538-47.

25. Jin G, Yang Y, Liu K, Zhao J, Chen X, Liu H, et al. Combination curcumin and (-)-epigallocatechin-3-gallate inhibits colorectal carcinoma microenvironment-induced angiogenesis by JAK/STAT3/IL-8 pathway. Oncogenesis. 2017 Oct;6(10):e384. https://doi.org/10.1038/oncsis.2017.84

26. Fei WJ, Yuan LP, Lu L, Gui JG. [Protective Effect of Total Flavones of Bidens pilosa L. on IgAl Induced injury of HUVECs in HenochSchönlein purpura children patients. Zhongguo Zhong Xi Yi Jie He Za Zhi. 2016 Feb;36(2):183-7. Chinese. 